\title{
Syntheses of Pyridazine Derivatives as Herbicides
}

\section{Part III. Preparation of 3- and 4-Phenoxypyridazines}

\author{
By Teruomi Jojima, Kozo Oyamada and Saburo Tamura* \\ Agricultural Chemicals Research Laboratory, Sankyo Co. Ltd., \\ Shinagaze-ku, Tokyo \\ * Department of Agricultural Chemistry, The University of Tokyo, \\ Bunkyo-ku, Tokyo \\ Received June 24, 1968
}

\begin{abstract}
Various 3-phenoxypyridazines were prepared by either catalytic dehalogenation of corresponding 3-phenoxy-6-chloropyridazines or reaction of 3-chloropyridazine with phenols in the presence of base. Syntheses of certain 4-phenoxypyridazines are also described.
\end{abstract}

In the course of our search for new series of herbicides, we discovered a group of halogeno-pyridazyl phenyl ethers with marked biological activity, such as 3-phenoxy-6-chloropyridazine (I) and 3-(2,6-dichlorophenoxy)-6chloropyridazine (II). ${ }^{1,2)}$

Further, we have recently found that 3phenoxypyridazine (III) without a chlorine atom on its pyridazine ring was by far the stronger herbicide than I and II in paddy field condition. ${ }^{3 /}$ This prompted us to prepare various 3-phenoxypyridazines along with certain 4-phenoxypyridazines containing respectively no substituents on their heterocyclic rings to be evaluated their herbicidal effects.

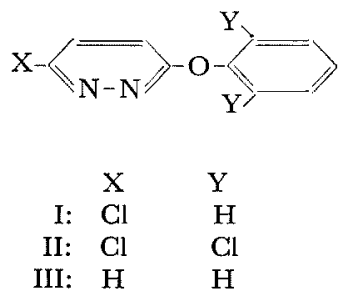

1) S. Tamura and T. Jojima, Agr. Biol. Chem., 27, 728 (1963).

2) T. Jojima and S. Tamura, ibid., 29, 157 (1965).

3) S. Tamura, T. Jojima, K. Kawakubo, K. Nakamura and $T$. Takematsu, ibid., 30, 423 (1966).
Concerning the synthesis of 3-phenoxypyridazines, only one example has been reported by Itai and Igeta, ${ }^{4}$ who prepared III by catalytic dehalogenation of I. In this paper syntheses of 3-phenoxypyridazines containing lower alkyl, phenyl, chlorine, nitro and methoxyl groups on their benzene rings are described. These compounds except nitrophenoxypyridazines were prepared by catalytic reduction of corresponding 3-phenoxy-6chloropyridazines over palladium on carbon or Raney nickel in ammoniacal methanol at room temperature and ordinary pressure. In a large-scale preparation, hydrogenation was carried out in an autoclave at $50 \sim 60^{\circ} \mathrm{C}$, initial pressure of hydrogen being $10 \sim 20 \mathrm{~kg} /$ $\mathrm{cm}^{2}$. Interestingly the chlorine atom attached to the benzene ring was never attacked during this process. On the other hand, all attempts to dehalogenate 3-phenoxy-6-chloropyridazines with zinc dust or iron powder in ethanol or acetic acid were unsuccessful, resulting in cleavage of the ether linkage.

Another synthetic route, in which 3-chloropyridazine (IV) and phenol are treated in the presence of base, was adopted to obtain

4) T. Itai and H. Igeta, J. Pharm. Soc. Japan, 74, 1195 (1954) 
TABLE I. 3-PhENOXYPYRIDAZINES

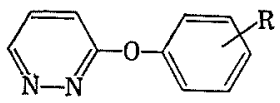

\begin{tabular}{|c|c|c|c|c|c|c|c|c|c|c|c|}
\hline \multirow{2}{*}{$R$} & \multirow{2}{*}{ Methoda) } & \multirow{2}{*}{$\begin{array}{l}\mathrm{mp}, \text { or } \\
\mathrm{bp},{ }^{\circ} \mathrm{C}\end{array}$} & \multirow{2}{*}{$\begin{array}{l}\text { Solvent } \\
\text { for } \\
\text { recrystn. }\end{array}$} & \multirow{2}{*}{$\begin{array}{c}\text { Yield, } \\
\%\end{array}$} & \multirow{2}{*}{$\begin{array}{l}\text { Molecular } \\
\text { formula }\end{array}$} & \multicolumn{3}{|c|}{ Calcd, $\%$} & \multicolumn{3}{|c|}{ Found, \% } \\
\hline & & & & & & $\mathrm{C}$ & $\widehat{H}$ & $\bar{N}$ & $\mathrm{C}$ & $\mathrm{H}$ & $\mathrm{N}$ \\
\hline $\mathrm{H}$ & A & $76^{b)}$ & Ligroin & 80 & - & - & - & - & - & - & - \\
\hline & B & $"$ & " & 13 & - & - & - & - & - & - & - \\
\hline 2- $-\mathrm{CH}_{3}$ & A & 78 & $" \prime$ & 88 & $\mathrm{C}_{11} \mathrm{H}_{10} \mathrm{~N}_{2} \mathrm{O}$ & 70.95 & 5.41 & 15.04 & 71.35 & 5.51 & 15.08 \\
\hline $3-\mathrm{CH}_{3}$ & A & 47 & " & 46 & " & $"$ & $"$ & " & 71.53 & 5.51 & 15.25 \\
\hline 4- $\mathrm{CH}_{3}$ & A & 94 & " & 72 & $"$ & " & " & $"$ & 70.57 & 5.14 & 15.04 \\
\hline $2-\mathrm{C}_{2} \mathrm{H}_{5}$ & A & $47 \sim 48$ & " & 38 & $\mathrm{C}_{12} \mathrm{H}_{12} \mathrm{~N}_{2} \mathrm{O}$ & 71.98 & 6.04 & +13.99 & 71.61 & 6.13 & 13.95 \\
\hline $2-n-\mathrm{C}_{3} \mathrm{H}_{7}$ & A & $58 \sim 61$ & " & 23 & $\mathrm{C}_{13} \mathrm{H}_{14} \mathrm{~N}_{2} \mathrm{O}$ & 72.87 & 6.59 & 13.07 & 72.24 & 6.53 & 12.54 \\
\hline $2-i-\mathrm{C}_{3} \mathrm{H}_{7}$ & A & $96.5 \sim 98$ & " & 58 & " & 1 & " & $"$ & 72.86 & 6.52 & 12.90 \\
\hline $2-n-\mathrm{C}_{4} \mathrm{H}_{9}$ & A & $127 \sim 136(0.4 \mathrm{~mm})$ & - & 49 & $\mathrm{C}_{14} \mathrm{H}_{15} \mathrm{~N}_{2} \mathrm{O}$ & 73.66 & 7.06 & 12.27 & 73.68 & 7.01 & 12.44 \\
\hline 2-sec- $\mathrm{C}_{4} \mathrm{H}_{9}$ & A & 53 & Ligroin & 38 & $"$ & " & " & $"$ & 73.59 & 7.15 & 12.47 \\
\hline $2-t-\mathrm{C}_{4} \mathrm{H}_{9}$ & A & $78 \sim 79$ & " & 72 & "r & " & $"$ & $"$ & 73.49 & 7.03 & 12.17 \\
\hline $4-t-\mathrm{C}_{4} \mathrm{H}_{9}$ & A & $121 \sim 123$ & " & 25 & $"$ & $"$ & $"$ & " & 2.60 & 7.12 & 11.86 \\
\hline $2-n-\mathrm{C}_{7} \mathrm{H}_{15}$ & A & $165 \sim 174(0.4 \mathrm{~mm})$ & - & 48 & $\mathrm{C}_{17} \mathrm{H}_{21} \mathrm{~N}_{2} \mathrm{O}$ & 75.80 & 7.86 & 10.40 & 75.30 & 8.41 & 9.74 \\
\hline 2, 3-di-CH ${ }_{3}$ & A & $88 \sim 95$ & Ligroin & 24 & $\mathrm{C}_{12} \mathrm{H}_{12} \mathrm{~N}_{2} \mathrm{O}$ & 71.98 & 6.04 & 13.99 & 69.98 & 5.94 & 13.48 \\
\hline 2, 4-di- $\mathrm{CH}_{3}$ & A & $66 \sim 68$ & " & 51 & " & $" 1$ & " & $"$ & 72.11 & 5.82 & 13.65 \\
\hline 2, 5-di- $\mathrm{CH}_{3}$ & A & $77 \sim 79$ & "r & 48 & $"$ & $"$ & " & $"$ & 71.41 & 6.04 & 14.60 \\
\hline 2, 6-di- $\mathrm{CH}_{3}$ & A & $94 \sim 95$ & $"$ & 19 & $"$ & $"$ & " & " & 72.98 & & 13.96 \\
\hline 3, 4-di- $\mathrm{CH}_{3}$ & A & $88 \sim 91$ & $"$ & 95 & 11 & $"$ & $"$ & $"$ & 71.41 & 6.15 & 14.26 \\
\hline $2-\mathrm{CH}_{3}-5$ & A & $142 \sim 150(0.07 \mathrm{~mm}$ & - & 39 & $\mathrm{C}_{14} \mathrm{H}_{16} \mathrm{~N}_{2} \mathrm{O}$ & 73.66 & 7.06 & 12.27 & & & 12.06 \\
\hline 3- $\mathrm{CH}_{3}-4$ & A & $135 \sim 143(0.04 \mathrm{~mm}$ & - & 43 & $"$ & $"$ & $"$ & " & 73.94 & 7.48 & 12.12 \\
\hline $2-i-\mathrm{C}_{8} \mathrm{H}_{7}-5-\mathrm{C}$ & A & $79 \sim 80$ & Ligroin & 49 & " & $"$ & " & " & 73.51 & 7.25 & 12.38 \\
\hline 2-sec- $\mathrm{C}_{4} \mathrm{H}_{9}-5-\mathrm{CH}_{3}$ & A & $57 \sim 58$ & $"$ & 45 & $\mathrm{C}_{15} \mathrm{H}_{18} \mathrm{~N}_{2} \mathrm{O}$ & 74.35 & 7.49 & 11.56 & 74 & 7. & 11.44 \\
\hline $3-\mathrm{CH}_{3}-4-\sec -\mathrm{C}_{4} \mathrm{H}_{9}$ & A & $55 \sim 165(0.05 \mathrm{~mm}$ & - & 46 & $"$ & " & " & " & 74.60 & 7.52 & 11.51 \\
\hline 2, 3, 5-tri-C & A & $132 \sim 135$ & Ligroin & 71 & c & 72.87 & 6.59 & 12.07 & 72 & 6 & 12.78 \\
\hline 2- $\mathrm{C}_{6} \mathrm{H}$ & B & $122 \sim 123$ & igroin-EtOH & I 24 & & 77.40 & 4.87 & 11.28 & & 4. & 11.28 \\
\hline 2-Cl & A & $108 \sim 109$ & " & 99 & $\mathrm{C}_{10} \mathrm{H}_{7} \mathrm{ClN}_{2} \mathrm{O}$ & 58.13 & 3.41 & 13.56 & 57 & 3. & 13.51 \\
\hline 3-Cl & $\begin{array}{l}\text { A } \\
\text { B }\end{array}$ & 90.5 & igroin & $\begin{array}{l}60 \\
18\end{array}$ & " & " & $"$ & " & 58.44 & 3 & 13.64 \\
\hline $4-\mathrm{Cl}$ & $\begin{array}{l}\text { A } \\
\text { B }\end{array}$ & 106 & $"$ & $\begin{array}{r}42 \\
8\end{array}$ & " & $"$ & $"$ & " & 58.33 & 3.34 & 14.50 \\
\hline 2, 4-di-Cl & $\begin{array}{l}\text { A } \\
\text { B }\end{array}$ & 98 & Ligroin & $\begin{array}{r}70 \\
8\end{array}$ & $\mathrm{C}_{10} \mathrm{H}_{6} \mathrm{Cl}_{2} \mathrm{~N}_{2} \mathrm{O}$ & 49.82 & 2.51 & 11.62 & 49.57 & 2.65 & 11.43 \\
\hline 2,6-di-Cl & $\begin{array}{l}\text { A } \\
\text { B }\end{array}$ & $87 \sim 88$ & Ligroin & $\begin{array}{r}59 \\
3\end{array}$ & נ & " & " & $"$ & 50.00 & 2.67 & 10.98 \\
\hline 4,5 & $\mathrm{~A}_{\mathrm{O}}>$ & $132 \sim 133$ & Ligroi & 56 & $\mathrm{H}_{5} \mathrm{Cl}_{3} \mathrm{~N}_{2} \mathrm{O}$ & 43.59 & 1.83 & 10.17 & & 1. & 10.10 \\
\hline 4,6 & 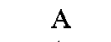 & & $"$ & 72 & -5 & $"$ & $"$ & " & & 1.87 & 10.26 \\
\hline 2- $\mathrm{CH}_{3}-4-\mathrm{Cl}$ & 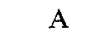 & $98 \sim 99$ & " & 53 & $\mathrm{C}_{11} \mathrm{H}_{9} \mathrm{ClN}_{2} \mathrm{O}$ & 59.87 & 4.11 & 12.70 & 59.01 & 4.11 & 12.50 \\
\hline $2-\mathrm{CH}_{3}-6-\mathrm{C}$ & 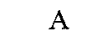 & 89 & " & 70 & " & $"$ & $"$ & $" \prime$ & 60.90 & 4.23 & 12.56 \\
\hline $3-\mathrm{CH}_{3}-4-\mathrm{Cl}$ & $\begin{array}{l}\text { A } \\
\text { B }\end{array}$ & 86 & 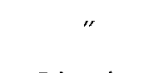 & $\begin{array}{l}77 \\
40\end{array}$ & 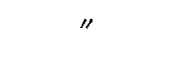 & 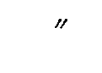 & " & $"$ & 59.97 & 4.32 & 12.58 \\
\hline 2-Cl-4 & A & $93 \sim 95$ & Ligroin & 50 & $\mathrm{O}$ & 67.97 & 3.92 & 9.91 & 66.65 & 3.93 & 9.75 \\
\hline & A & 126 &. & 55 & & 51.79 & 3.16 & 10.98 & & 3.32 & 10.87 \\
\hline $3-\mathrm{NO}_{2}$ & 15 & 86 & $\mathrm{EtOH}-\mathrm{H}_{2} \mathrm{O}$ & 37 & $\mathrm{C}_{10} \mathrm{H}_{7} \mathrm{~N}_{3} \mathrm{O}_{3}$ & 55.30 & 3.25 & 19.35 & 55.22 & 3.41 & 19.07 \\
\hline $4-\mathrm{NO}_{2}$ & B & 151 & Ligroin & 4 & & " & $"$ & $"$ & 55.08 & 3.30 & 19.18 \\
\hline $4-\mathrm{CH}_{3} \mathrm{O}$ & B & 88.5 & " & 30 & $\mathrm{C}_{11} \mathrm{H}_{10} \mathrm{~N}_{2} \mathrm{O}_{2}$ & 65.34 & 4.98 & 13.85 & 65.06 & 4.95 & 13.78 \\
\hline
\end{tabular}

a) A: Catalytic hydrogenation of 3-phenoxy-6-chloropyridazines.

B: Reaction of 3-chloropyridazine (IV) with phenols in the presence of base.

b) Lit.4) $\mathrm{mp} 74^{\circ} \mathrm{C}$. 
certain phenoxypyridazines, especially those containing nitro groups on their benzene rings. Owing to the heat-instability of IV, however, yields were generally poor as compared with those in the hydrogenation procedure mentioned above. For example, III was obtained in an $8 \%$ yield by the fusion of IV with phenol in the presence of anhydrous potassium carbonate for $15 \mathrm{~min}$ at $120^{\circ} \mathrm{C}$, and only $0.5 \%$ by the treatment of IV with sodium phenoxide in boiling benzene for several hrs. On the other hand, catalytic dehalogenation of I over $5 \%$ palladium on carbon in ammoniacal methanol at ordinary pressure and room temperature afforded III in a $90 \%$ yield. Various 3-phenoxypyridazines prepared by the both methods are listed in Table I.

In the preceding papers, ${ }^{5,6)}$ 3-phenoxy-6chloropyridazines, which are also required in the present study as the starting materials, were synthesized by treating various phenols with 3,6-dichloropyridazine (V) in the presence of metalic sodium in boiling benzene or toluene. To obtain mono-ethers by this method, however, so large excess of phenols should be used respectively, that formation of undersirable bis-ethers often ensued. Especially 0 -halophenols, such as 0 -chloro, 0 bromo- and 2-chloro-4-phenylphenols did not give corresponding mono-ethers, but afforded bis-ethers in low yields irrespective of amounts of phenols employed. In order to avoid these difficulties, reaction conditions were examined for the preparation of 3-(2-methylphenoxy)-6chloropyridazine (VI) from $o$-cresol (VII) and $\mathrm{V}$ according to various procedures, and yields were accurately measured with gas chromatography, since 3-(2-methylphenoxy) pyridazine (VIII) derived from VI seemed promising as a practical herbicide. The results are shown in Table II. When V, VII and anhydrous potassium carbonate in an equimolar ratio were heated at $160^{\circ} \mathrm{C}$ without any solvent

5) S. Tamura and T. Jojima, Agr. Biol. Chem., 27, 653 (1963).

6) T. Jojima and S. Tamura, ibid., 29, $15 \mathrm{I}$ (1965).
TABLE II. REACTION OF o-CRESOL AND 3,6-DICHLOROPYRIDAzINe to Produce 3-(2-MethyLPHENOXY)-6-CHLOROPHENOXYPYRIDAZINE (VI) IN VARIOUS CoNDITIONS

$\begin{array}{lccccc}\begin{array}{c}\text { Base } \\ \text { (equiv) }\end{array} & \begin{array}{c}\text { o-Cresol, } \\ \text { equiv }\end{array} & \text { Solvent } & \begin{array}{c}\text { Time, } \\ \text { hr }\end{array} & \begin{array}{c}\text { Temp., } \\ { }^{\circ} \mathrm{C}\end{array} & \begin{array}{c}\text { Yield, } \\ \%\end{array} \\ \mathrm{Na}(1) & \begin{array}{c}\text { Excess } \\ \prime \prime\end{array} & - & 2 & 180 & 5.3{ }^{\text {9) }} \\ \mathrm{Na}(2) & 4 & \text { Toluene } & 2 & \text { Reflux } & 73.4 \\ \mathrm{NaOH}(1) & 1 & \prime \prime & 2 & { }^{\prime \prime} & 18.0 \text { s) } \\ { }^{\prime \prime} & 4 & \text { Water } & 4 & 80 & 26.4 \\ \mathrm{~K}_{2} \mathrm{CO}_{3}(1) & 1 & - & 4 & 80 & 60.7 \\ \end{array}$

a) Large quantity of bis-ether, 3, 6-di (2-methylphenoxy)pyridazine was produced.

for $30 \mathrm{~min}$, VI was obtained in the best yield (85.1\%). Treatment of V, VII and metalic sodium according. to the previous method ${ }^{1 \prime}$ in the molar ratio of $1: 4: 1$ in boiling toluene gave VI in a yield of 73.4\%. Increase of the ratio of VII or metalic sodium to V significantly reduced the yield of VI. Furthermore, the reaction carried out in aqueous sodium hydroxide solution showed a poorer yield. Thus, all the 3-phenoxy-6-chloropyridazines mentioned here were prepared by the fusion of $\mathrm{V}$ with phenols in the presence of potassium carbonate. By this procedure 0 chlorophenol and 2-chloro-4-phenylphenol afforded respectively the anticipated monoethers, which could not be obtained previously, in fairly good yields, still 2-methyl-6-t-butylphenol and 2,6-di-t-butylphenol did not react with $V$ probably due to the bulky substituent on the ortho-position. In Table III, only new 3-phenoxy-6-chloropyridazines are illustrated.

Though syntheses of certain 4-phenoxy-3, 6dichloropyridazines were reported in the previous paper, ${ }^{61}$ 4-phenoxypyridazines without any substituent on their heterocyclic rings have not been hitherto reported. Then, 3,4,5-trichloropyridazine (IX) was heated with phenol or $p$-methoxyphenol in the presence of anhydrous potassium carbonate to give the corresponding 5-phenoxy-3,4-dichloro-3 pyridazine ( $\mathrm{Xa}$ or $\mathrm{Xb}$ ), which was subsequently dehalogenated catalytically to 4-phenoxypyridazine (XIa or XIb). XIa was also 


\section{TABLE III. 3-PHENOXY-6-CHLOROPYRIDAZINES}

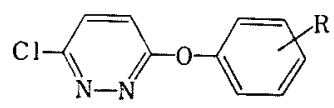

R mp or Solvent for Yield, Molecular

2, 4-di-Cl-6- $\mathrm{CH}_{3}$

2- $\mathrm{C}_{2} \mathrm{H}_{5}$

$2-n-\mathrm{C}_{3} \mathrm{H}_{7}$

$2-n-\mathrm{C}_{4} \mathrm{H}_{9}$

$2-\sec -\mathrm{C}_{4} \mathrm{H}_{9}$

$2-t-\mathrm{C}_{4} \mathrm{H}_{9}$

4- $t-\mathrm{C}_{4} \mathrm{H}_{9}$

$2-n-\mathrm{C}_{7} \mathrm{H}_{15}$

2, 3-di- $\mathrm{CH}_{3}$

2, 4-di- $\mathrm{CH}_{3}$

2, 5-di-CH

2, 6-di- $\mathrm{CH}_{3}$

2- $\mathrm{CH}_{3}-5-i-\mathrm{C}_{3} \mathrm{H}_{7}$

$3-\mathrm{CH}_{3}-4-i-\mathrm{C}_{3} \mathrm{H}_{7}$

$2-i-\mathrm{C}_{3} \mathrm{H}_{7}-5-\mathrm{CH}_{3}$

2-sec $-\mathrm{C}_{4} \mathrm{H}_{9}-5-\mathrm{CH}_{3}$

3- $\mathrm{CH}_{3}-4-\mathrm{sec}-\mathrm{C}_{4} \mathrm{H}_{9}$

2, 3, 5-tri- $\mathrm{CH}_{3}$

2-Cl

2, 4, 6-tri-CI

2- $\mathrm{CH}_{3}-4-\mathrm{Cl}$

$2-\mathrm{CH}_{3}-6-\mathrm{Cl}$

2- $\mathrm{Cl}-4-\mathrm{C}_{6} \mathrm{H}_{5}$

$$
\text { crystn } \% \text { formula }
$$

Ligroin-EtOH

$130 \sim 142(0.04 \mathrm{~mm})$

$82 \sim 83$

$156 \sim 165(0.18 \mathrm{~mm})$

$92 \sim 94$

$109 \sim 110$

$112 \sim 114$

$178 \sim 187(0.25 \mathrm{~mm})$

$95 \sim 96$

67

$77 \sim 79$

$94 \sim 95$

$145 \sim 149(0.12 \mathrm{~mm})$

84

$85 \sim 87$

72

$165 \sim 175(0.4 \mathrm{~mm})$

$130 \sim 131$

$68 \sim 69$

$167 \sim 168$

$92 \sim 94$

$101 \sim 102$

$102 \sim 106$

Ligroin

Ligroin

37

92

95

"

Ligroin
$\mathrm{C}_{11} \mathrm{H}_{7} \mathrm{Cl}_{3} \mathrm{~N}_{2} \mathrm{O}$

$46 \mathrm{C}_{12} \mathrm{H}_{11} \mathrm{~N}_{2} \mathrm{ClO}$

$56 \mathrm{C}_{13} \mathrm{H}_{13} \mathrm{ClN}_{2} \mathrm{O}$

$\overbrace{\mathrm{H} \quad \mathrm{N}}^{\text {Calcd, }:_{\mathrm{O}}} \overbrace{\mathrm{H}}^{\text {Found, }: \dot{O}}$

$\begin{array}{llllll}45.63 & 2.44 & 9.68 & 46.30 & 2.43 & 9.90\end{array}$

$61.42 \quad 4.72 \quad 11.94 \quad 61.50 \quad 4.70 \quad 11.99$

$\begin{array}{lllllll}62.78 & 5.27 & 11.26 & 62.75 & 5.36 & 11.26\end{array}$

$47 \quad \mathrm{C}_{14} \mathrm{H}_{15} \mathrm{ClN}_{2} \mathrm{O} \quad 64.00 \quad 5.75 \quad 10.66 \quad 63.62 \quad 5.74 \quad 10.57$

$45 \mathrm{C}_{17} \mathrm{H}_{21} \mathrm{ClN}_{2} \mathrm{O}$

" " $\quad 63.91 \quad 5.70 \quad 10.70$

" " $\quad 64.095 .7910 .72$

" " " $63.84 \quad 5.71 \quad 10.44$

$\mathrm{C}_{12} \mathrm{H}_{11} \mathrm{~N}_{2} \mathrm{ClO}$

$\begin{array}{llllll}66.98 & 6.94 & 9.19 & 66.32 & 6.93 & 9.10\end{array}$

$\begin{array}{llll}61.42 & 4.72 \quad 11.9461 .59 & 4.83 & 12.00\end{array}$

91 " " " 61.204 .8711 .86

87 " " " " 61.244 .8912 .17

93 " " " " 61.304 .7912 .16

$\begin{array}{llllllll}58 & \mathrm{C}_{14} \mathrm{H}_{15} \mathrm{CIN}_{2} \mathrm{O} & 64.00 & 5.75 & 10.66 & 63.20 & 5.81 & 10.30\end{array}$

81 " " "

52 " " "

$\begin{array}{llllllll}42 & \mathrm{C}_{15} \mathrm{H}_{17} \mathrm{CIN}_{2} \mathrm{O} & 65.09 & 6.19 & 10.12 & 65.01 & 6.21 & 10.15\end{array}$

45 " " "

$\begin{array}{lllllllll}\text { Ligroin } & 61 & \mathrm{C}_{13} \mathrm{H}_{13} \mathrm{ClN}_{2} \mathrm{O} & 62.78 & 5.27 & 11.26 & 62.67 & 5.29 & 11.36\end{array}$

Ligroin-pet.-ether $94 \quad \mathrm{C}_{10} \mathrm{H}_{6} \mathrm{Cl}_{2} \mathrm{~N}_{2} \mathrm{O} \quad 49.82 \quad 2.51 \quad 11.6249 .92 \quad 2.62 \quad 11.51$

$\begin{array}{lllllllll}\text { Acetone-EtOH } \quad 53 \quad \mathrm{C}_{10} \mathrm{H}_{4} \mathrm{Cl}_{4} \mathrm{~N}_{2} \mathrm{O} & 38.75 & 1.30 & 9.04 & 38.75 & 1.43 & 9.11\end{array}$

Ligroin $\quad 100 \quad \mathrm{C}_{11} \mathrm{H}_{8} \mathrm{Cl}_{2} \mathrm{~N}_{2} \mathrm{O} \quad 51.79 \quad 3.16 \quad 10.98 \quad 51.47 \quad 3.30 \quad 11.19$

" 80 " " $" 51.573 .1011 .21$

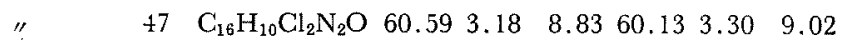<smiles>[R]CC=C(C)O</smiles>

IX<smiles>Oc1ccccc1Cl</smiles>

$\downarrow \mathrm{K}_{2} \mathrm{CO}_{3}$

XII<smiles>CCCC(=O)O</smiles><smiles>[R][R]([R])=[W]</smiles><smiles></smiles>

$\mathrm{H}_{2} / \mathrm{Pd}-\mathrm{C}$

$\mathrm{H}_{2} / \mathrm{Pd}-\mathrm{C}$

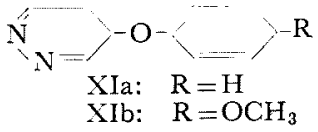


TABLE IV. 4-PHENOXYPYRIDAZINES

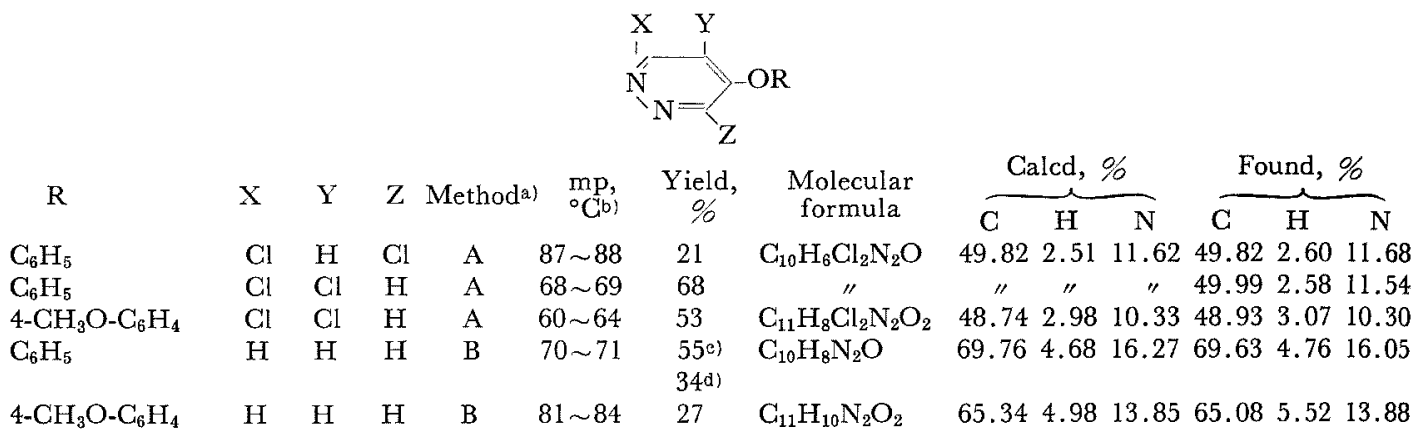

a) A: From trichloropyridazine, phenol and anhyd. $\mathrm{K}_{2} \mathrm{CO}_{3}$.

B: Catalytic hydrogenation of dichlorophenoxypyridazines.

b) All samples are recrystallized from ligroin.

c) From 3,6-dichloro-4-phenoxypyridazine.

d) From 3, 4-dichloro-5-phenoxypyridazine.

obtained through the reaction of 3,4,6-trichloropyridazine (XII) with phenol, followed by hydrogenation of resulting 4-phenoxy-3, 6dichloropyridazine (XIII). Physical properties of these 4-phenoxypyridazines are shown in Table IV. Herbicidal activities of these pyridazine derivatives will be disclosed in the succeeding paper.

\section{EXPERIMENTAL}

Preparation of 3-phenoxy-6-chloropyridazines. In general, an equimolar mixture of phenol, 3,6dichloropyridazine (V) and anhydrous potassium carbonate was heated at $160 \sim 180^{\circ} \mathrm{G}$ for $30 \sim 60 \mathrm{~min}$. After cooling, dilute aqueous sodium hydroxide solution was added to the reaction mixture, from which crude 3mphenoxy-6-chloropyridazine was usually separated as crystals. Then the product was filtered and recrystallized from an appropriate solvent. On the other hand, when the product was a liquid as in the case of the reaction between $0-n$-butylphenol and $\mathrm{V}$, the alkaline solution was repeatedly extracted with ether. After evaporation of the solvent, the residue was distilled under reduced pressure to give a pure product. Synthesis of 3-(2-methylphenoxy)-6-chloropyridazine (VI) is illustrated below as a typical run.

An equimolar mixture (0.134 mole each) of $14.5 \mathrm{~g}$ of o-cresol, $20.0 \mathrm{~g}$ of $\mathrm{V}$ and $18.5 \mathrm{~g}$ of anhydrous potassium carbonate was heated at $160^{\circ} \mathrm{C}$ in an oil bath for $30 \mathrm{~min}$. After cooling, the reaction mixture was treated with $2 \mathrm{~N}$ sodium hydroxide solution and the resulting crude crystalline solid (28.8g) was filtered and washed with water. Recrystallization from ligroin gave VI as colorless rods, $\mathrm{mp} 85 \sim 86^{\circ} \mathrm{C}$.

In order to measure exactly the yields of VI, which was prepared in the various ways including the above procedure, an F \& M Model 402 gas chromatograph was used under the following conditions: stainless steel tubing, $1 \mathrm{~m}$ by $3.2 \mathrm{~mm}$, packed with $1 \%$ XE-60 on $80 / 100$ mesh Chromosorb; column temperature, $260^{\circ} \mathrm{C}$; hydrogen flow, $40 \mathrm{ml} / \mathrm{min}$. The results are shown in Table II.

Catalytic dehalogenation of 3-phenoxy-6-chloropyridazines to 3 -phenoxypyridazines. The reactions were conducted in a glass hydrogenating apparatus over $5 \% \mathrm{Pd}-\mathrm{G}$ in ammoniacal methanol at room temperature and ordinary pressure. Sometimes, the apparatus was externally warmed to $50 \sim 60^{\circ} \mathrm{C}$ to promote hydrogenation. In a preparative scale, the reduction was conducted in a stainless steel autoclave. Typical runs are given below.

Twenty $g$ (0.91 mole) of 3-(2-methylphenoxy)-6chloropyridazine (VI) dissolved in a mixture of 100 $\mathrm{ml}$ of ethanol and $8 \mathrm{ml}$ of concentrated aqueous ammonia was hydrogenated over $1.6 \mathrm{~g}$ of $5 \% \mathrm{Pd}-\mathrm{G}$ in 1-1 glass hydrogenating apparatus at $50^{\circ} \mathrm{C}$ and ordinary pressure. One equivalent of hydrogen was absorbed within $40 \mathrm{~min}$. The reaction mixture was filtered to remove the catalyst, and the filtrate was evaporated under reduced pressure. A small amount of water was added to the residue, which was then extracted with ether. After removal of the solvent, there remained $15 \mathrm{~g}$ of $3-(2$-methylphenoxy) pyri- 
dazine (VIII) as colorless needles, $\mathrm{mp} 78 \sim 80^{\circ} \mathrm{C}$.

For the large scale preparation of VIII, $2 \mathrm{~kg}$ of VI, 10 liters of methanol, $80 \mathrm{ml}$ of water, $700 \mathrm{ml}$ of concentrated aqueous ammonia and $80 \mathrm{~g}$ of $50^{\circ} \mathrm{Pd}-\mathrm{C}$ were charged in a 20-1 autoclave. Hydrogenation was conducted at $50 \sim 70^{\circ} \mathrm{C}$, initial hydrogen pressure being $10 \mathrm{~kg} / \mathrm{cm}^{2}$. Then, the reaction mixture was treated as described above to give $1.65 \mathrm{~kg}$ of crude crystalline VIII melting at $76^{\circ} \mathrm{C}$.

Preparation of 3-phenoxypyridazines from 3chloropyridazine (IV) and phenols. As typical runs, syntheses of 3-phenoxypyridazine (III) from 3chloropyridazine (IV) and phenol in the presence of anhydrous potassium carbonate and metalic sodium are described below.

An equimolar mixture ( 0.017 mole each) of $2 \mathrm{~g}$ of IV, $1.69 \mathrm{~g}$ of phenol and $2.4 \mathrm{~g}$ of anhydrous potassium carbonate was heated at $120^{\circ} \mathrm{C}$ for $15 \mathrm{~min}$. During the reaction vigorous decomposition of IV was observed. After cooling, the reaction mixture was treated with $100 \mathrm{ml}$ of $2 \mathrm{~N}$ sodium hydroxide and stood overnight. The resulting crystals were filtered to give $0.4 \mathrm{~g}$ of 3 -phenoxypyridazine (III), as colorless crystals, mp $71^{\circ} \mathrm{C}$, lit. $44^{4} 74^{\circ} \mathrm{C}$.

Alternatively, $2.0 \mathrm{~g}(0.017 \mathrm{~mole})$ of IV, $3 \mathrm{~g}(0.032$ mole) of phenol, $0.39 \mathrm{~g}$ ( 0.017 mole) of metalic sodium and $20 \mathrm{ml}$ of benzene were treated according to the procedure described previouslys) to give $15 \mathrm{mg}$ of III.

Preparation of 4-phenoxypyridazines. As typical runs, syntheses of 4-phenoxypyridazine (XIa) are shown below.

a) From 3, 4, 5-trichloropyridazine (IX). An equimolar mixture $(0.038$ mole each) of $7 \mathrm{~g}$ of IX,
$3.6 \mathrm{~g}$ of phenol and $5.3 \mathrm{~g}$ of anhydrous potassium carbonate was heated at $160^{\circ} \mathrm{C}$ for $15 \mathrm{~min}$. The reaction mixture was treated with $2 \mathrm{~N}$ sodium hydroxide and repeatedly extracted with ether. The combined extracts were evaporated and the residue was fractionally distilled under reduced pressure. A fraction boiling in the range of $130 \sim 150^{\circ} \mathrm{C} / 0.27$ $\mathrm{mmHg}$ gave $6.1 \mathrm{~g}$ of semi-solid crystals, a part of which was recrystallized for analysis from ligroin to yield colorless crystals of 3, 4-dichloro-5-phenoxypyridazine $(\mathrm{Xa}), \mathrm{mp} 68 \sim 69^{\circ} \mathrm{C}$. Hydrogenation of $4 \mathrm{~g}$ of crude $\mathrm{Xa}$ afforded $1.2 \mathrm{~g}$ of solid product. $\mathrm{Re}-$ crystallization from ligroin gave $1.0 \mathrm{~g}$ of 4-phenoxypyridazine (XIa) as colorless crystals, mp $70 \sim 71^{\circ} \mathrm{C}$.

b) From 3, 4, 6-trichloropyridazine (XII). An equimolar mixture $(0.043$ mole each) of $8 \mathrm{~g}$ of XII, $4.1 \mathrm{~g}$ of phenol and $5.96 \mathrm{~g}$ of anhydrous potassium carbonate was treated as described above. A fraction boiling in the range of $136 \sim 179^{\circ} \mathrm{C} / 0.5 \mathrm{mmHg}$ was collected and stood overnight to become solid. Recrystallization from ligroin gave $2.1 \mathrm{~g}$ of 3,6 -dichloro4-phenoxypyridazine (XIII), $\mathrm{mp} 87 \sim 88^{\circ} \mathrm{C}$. Hydrogenation of $1.5 \mathrm{~g}$ of XIII in the usual manner afforded $0.59 \mathrm{~g}$ of the crude product. Recrystallization from ligroin-petroleum ether gave colorless leaflets, mp $71 \sim 72^{\circ} \mathrm{C}$, which was identified as XIa by the mixture melting point as well as by the comparison of infrared and NMR spectra.

Acknowledgement. The authors wish to thank Mr. J. Tobitsuka and Miss Y. Mochizuki of Sankyo Co., Ltd. for their assistance in the experimental works. 